\title{
Alerjik rinitli bir olguda eozinofilik özofajit
}

\author{
Allergic rhinitis in eosinophilic esophagitis
}

\author{
Fatma DÜşÜNÜR GÜNSEN'¹, Serhat BOR², Murat SEZAK², Aytül Zerrin SiN¹ \\ Ege Üniversitesi Tıp Fakültesi, İç Hastalıkları Anabilim Dalı, ${ }^{1}$ Alerji ve Klinik İmmünoloji Bilim Dalı, ${ }^{2}$ Gastroenteroloji Bilim Dalı, \\ ${ }^{3}$ Patoloji Anabilim Dalı, İzmir
}

Eozinofilik özofajit; özofagus mukozasında eozinofilik infiltrasyon ile karakterize kronik, immün aracılı bir tablodur. Erişkinlerde özofageal disfonksiyon semptomları olan disfaji, gıda takılma hissi, regürjitasyon, kusma ve göğüs ağrısı en sık görülen yakınmalardır. Tanı hastanın semptomları eşliğinde endoskopik ve histolojik bulgular ile konur. Bu olguda alerjik riniti ve eozinofilik özofajiti olan bir hasta tanımlanmaktadır.

Anahtar kelimeler: Disfaji, eozinofilik infiltrasyon, alerjik rinit
Eosinophilic esophagitis is a chronic, immune-mediated disease that is characterized by eosinophilic infiltration into the esophagus mucosa. In adults, the symptoms of esophageal dysfunction include dysphagia, food bolus impaction, regurgitation, vomiting, and chest pain. The diagnosis of eosinophilic esophagitis should be based on the symptoms, endoscopic appearance of the esophagus mucosa, and histological findings. This case report describes a 23-year-old male with eosinophilic esophagitis and allergic rhinitis.

Key words: Dysphagia, eosinophilic infiltration, allergic rhinitis

\section{GíRiş}

Eozinofilik özofajit (EÖ); kronik, immün aracılı, eozinofilden zengin inflamasyonla seyreden özofagus disfonksiyonu ile karakterize bir hastalıktır (1). Normal şartlarda özofagus eozinofilden yoksundur. Özofagusta eozinofil infiltrasyonunun gösterilmesi tipik olarak eozinofilik özofajit veya gastrointestinal reflü hastalığını düşündürmektedir $(2,3)$. Eozinofilik özofajitli olguların \%75'i atopik yapıda olup; çoğunlukla gıda, ikinci sırada da inhalen alerjen duyarlıı̆ı saptanmaktadır.

\section{OLGU SUNUMU}

23 yaşında erkek hasta, alerji kliniğimize başvurusunda 10 yaşından beri yıl boyu süren ancak özellikle bahar aylarında yoğunlaşan şiddetli burun akıntısı, burun kaşıntısı, damakta kaşıntı, gözlerde kızarıklık ve kaşıntı şeklinde şiddetli alerjik rinit ve konjonktivit semptomları mevcuttu. Öksürük, nefes darlığı veya hırıltı gibi astım semptomları yoktu. Ayrıca sorgulamasında 2-3 yıldır olan, son 3 ayda artış gösteren ve özellikle bahar aylarında olan gıdalarla boğazda takılma hissi, yutma güçlüğü ve kusma yakınması mevcuttu. Fizik muayenesinde; tansiyon arteriyel (TA): 120/80 mmHg, nabız (Nb): 75/dk, konjonktivalar hiperemik, burun bakısında mukoza soluk izlendi, hafif sulu sekresyonu mevcuttu. Solunum sistemi muayenesi

ve diğer sistem muayeneleri olağandı. Kulak burun boğaz tarafından yapılan fizik muayenesinde de burun mukozası soluk, rinitle uyumlu mukozal değişiklikler olup polip saptanmadı. Nazal smear örneklemesi rutin uygulamada kullanımadığından ve tanıya ek fayda sağlamadığından yapılmadı. Özgeçmişinde ek hastalık öyküsü, sigara kullanımı, operasyon öyküsü yoktu; soy geçmişinde ailesinde alerjik hastalık öyküsü yoktu. 13 yaşına kadar evde kedi beslediği ancak 10 yıldır kedisinin olmadığı öğrenildi. Buna rağmen hastanın rinit semptomları kedi teması ile belirgin olarak artıyordu. Mevcut rinit yakınmaları ile çeşitli merkezlere başvurmuş, değişik antihistaminik tablet ve nazal steroid tedavileri kullanmasına rağmen rinit yakınmaları hiçbir zaman tam olarak gerilememişti. Hastanın kan biyokimyasında karaciğer ve börek fonksiyon

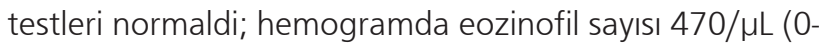
$500 / \mu \mathrm{L})$, normal sınırlarda idi, bu değer periferik yayma ile doğrulandı. Total (immünglobulin $\mathrm{E}$ ) IgE seviyesi 36.1 IU/mL (0-100 IU/mL) normal, GX1 (Grass Panel-ot karışImı paneli) spesifik IgE: $0.58 \mathrm{kUA} / \mathrm{l}$ Rast Mtd ( >0.35 pozitif) pozitif, WX3 (Weed Panel-yabani ot karışımı paneli) spesifik IgE: $0.36 \mathrm{kUA} / \mathrm{l}$ Rast Mtd ( $>0.35$ pozitif) pozitif saptandı. Deri prik testinde ot polenleri +3 , sinir otu +2 , kedi +3 pozitif saptandı. Gıda alerjisi açısından yapılan 
testleri negatifti. Gastroenteroloji tarafından yapılan gastroskopide; distal özofagusta geçişi daraltmayan Schatzki halkası ve hiatus hernisi izlendi. Alınan biyopsilerde; distal özofagusta skuamöz epitel içerisinde bir büyük büyütme alanında 30 ve üzeri; proksimal özofagusta bir büyütme alanında 20 eozinofil izlendi; bulgular eozinofilik özofajit ile uyumlu olarak yorumlandı (Resim 1 A-B). Gastroözofageal reflü hastalığı açısından yapılan özofagus manometrisi, empedans ve $\mathrm{pH}$ analiz sonuçları normaldi. Hastaya eozinofilik özofajit ve alerjik rinit tanısı konarak rinite yönelik polenlerle sublingual immünoterapi (OralAir $\left.{ }^{\circledR}\right)$ başlandı, özofajite yönelik oral budesonid kapsül $400 \mathrm{mcg}$ 2,5 ay süreyle verildi. Tedavinin birinci ayının sonunda hastanın gıda alımı sonrası ortaya çıkan klinik yakınmaları ve alerjik rinit semptomları düzeldi.

\section{TARTIȘMA}

Eozinofilik özofajit; ilk olarak 1970'li yıllarda tanımlanmış olup, farkındalığın artması ve tanı yöntemlerinin gelişmesi ile son yıllarda insidansı artmakta olan bir hastalıktır $(4,5)$. Gastroözofageal reflü tanısına sahip hastaların aslında yaklaşık \%6-10'unda gerçek tanının EÖ olduğunu öne süren yayınlar mevcuttur (6). Yetişkinlerde genellikle erkeklerde görülmekte olup; hastaların yaklaşık \%6070'inde periferik eozinofili, artmış serum total IgE düzeyi ile alerjik astım, alerjik rinit veya atopik dermatit gibi alerjik hastalıklar eşlik edebilmektedir (7). Çocuklarda ise gıda alerjisi birlikteliği solunum yolu alerjilerine göre daha sık rastlanmaktadır. Bizim olgumuzda da yapılan testlerde gıda duyarlıı̆̆ı saptanmamış olup, tablo aeroalerjenlerle ilişkilendirilmiştir. Solunum yoluyla alınan alerjenlerin özofagusa ulaşanlarının burada inflamasyonu başlattığı ve bu yolla özofagusta eozinofil infiltrasyonu oluştuğu düşünülmektedir (8).
Hastaların klinik yakınmaları yaşa göre değişkenlik gösterebilmektedir. Yetişkin hastalarda ilk yakınma sıklıkla katı gıdalara karşı gelişen disfajidir. Buna ek olarak gıda takılma hissi, tedaviye yanıtsız reflü yakınmaları ve üst batın ağrısı olabilmektedir (9). Ayrıca literatürde özofagusta motilite bozukluğu, striktürler, spontan özofagus perforasyonu (Boerhaave sendromu) veya endoskopi sırasında özofagus perforasyonu gibi klinik durumlar da tanımlanmıştır. Disfaji nedeniyle endoskopi yapılan hastaların yaklaşık \%15'inde EÖ saptanmaktadır (10). Çocuklarda ise klinik bulgularda yutma problemleri, kusma, karın ağrısı ve ilerleyen olgularda büyüme-gelişme geriliği ön planda olmaktadır.

Tanı yaşı yetişkinlerde 20-30 arasındadır. Tanı klinik bulgular eşliğinde endoskopik biyopsi ve histolojik inceleme ile konmaktadır. Histolojik incelemede; mukozal eozinofili, eozinofil mikroabseleri, ekstrasellüler alanlarda eozinofil granülleri, yüzey epitelinde deskuamasyon, bazal zon hiperplazisi, intersellüler alanlarda dilatasyon, subepitelyal fibrozis/sklerozis/lamina propriada fibrozis görülebilmektedir (1). Buna göre tanı için; bir büyük büyütme alanında 15 ve üzeri eozinofil görülmesi, klinik bulgu olması, gastrointestinal sistemde özofagusa sınırlı eozinofil infiltrasyonu olması, sekonder özofageal eozinofili nedenlerinin dışlanması (reflü gibi...) ve bu bulgular eşliğinde diyet-steroid tedavisi ile klinik yanıt alınması gerekmektedir (11). Özofagusta eozinofili saptanabilecek ayırıcı tanıda düşünülmesi gereken hastalıkların başında gastroözofageal reflü gelmektedir. Bunun dışında da; eozinofilik gastrointestinal hastalık, çölyak hastalığı, Crohn hastalığı, enfeksiyonlar, hipereozinofilik sendrom, akalazya, ilaç hipersensitivitesi, vaskülitler, pemfigus vegetans, bağ doku hastalıkları, graft versus host hastalığı gibi birçok değişik klinik durumda da özofageal eozinofil infiltrasyonu olabilmektedir, ayırıcı tanıda akla gelmelidir (1).
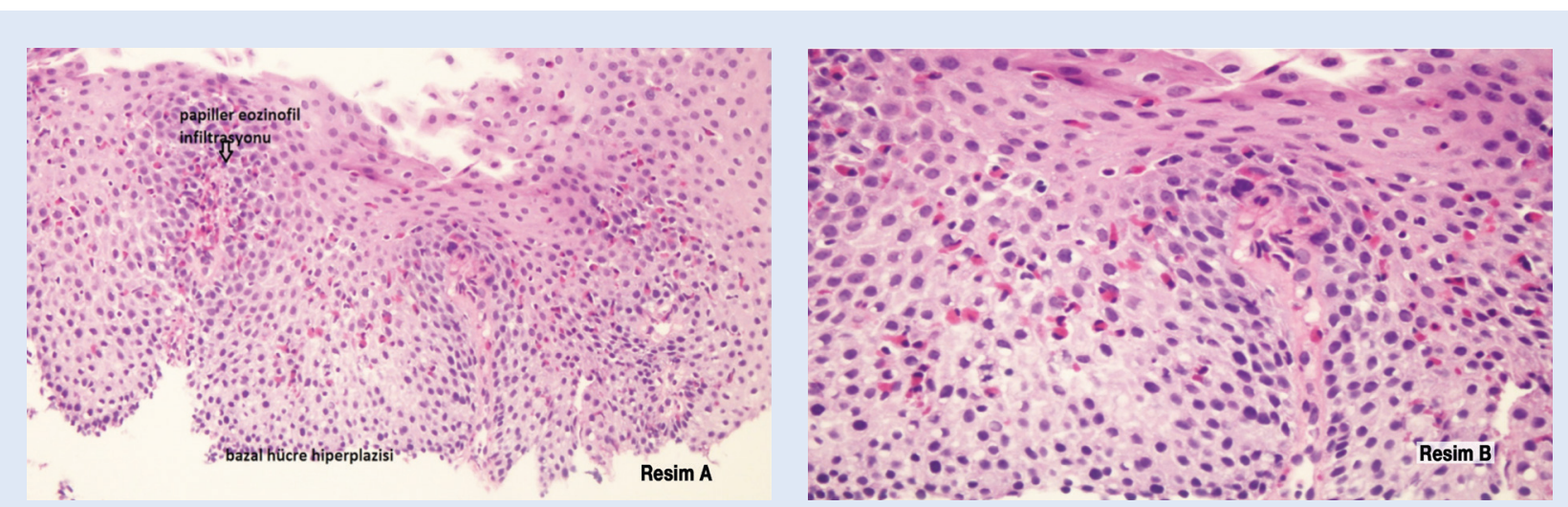

Resim 1 A,B. Çok katlı yassı epitelde yoğun bazal hücre hiperplazisi, papiller elongasyon (\%80-90), bir büyük büyütme alanında > 40 eozinofil infiltrasyonu (**Resim A 10x, Resim B 40x büyütme). 
Tedavide özellikle gıda alerjisi saptanan vakalarda gıda eliminasyon diyetleri önerilmekte, alerjenle temas kesilince tablo düzelebilmektedir. Ancak gıda alerjisi saptanamaması durumunda elemental diyet gibi uygulaması zor diyet tedavileri hem hasta açısından uygulaması zor olduğundan hem de kanıt düzeyi düşük olduğundan önerilmemektedir. Farmakolojik tedavide öncelikle asit süpresyonu (proton pompa inhibitörleri ile) yapılmalı, özellikle altta reflü gibi klinik tabloyu karıştıran bir durum var ise düzeltilmelidir. Öncelikle en az iki ay gibi bir süre ile bu tedavinin verilmesi ve sonrasında kontrol endoskopi ile değerlendirme yapılması önerilmektedir (12). Topikal kortikosteroidler esas tedaviyi oluşturan ajanlardır. Budesonid ve flutikazon bu konuda en çok çalsşllan steroid- ler olup, kullanılacak süre ya da hasta seçimi konusunda randomize kontrollü çalışmalar bulunmamaktadır. Ancak genel kullanımda olan yetişkin dozları şu şekildedir; flutikazon inhaler yetişkin dozu 440-880 mcg- günde 2 kez, budesonid süspansiyon $2 \mathrm{mg} / \mathrm{gün}$. Hastaların bu tedaviyi kullanırken ilaç alımından sonra $30 \mathrm{dk}$ herhangi bir şey yememesi-içmemesi önerilmektedir. Daha ağır hastalık durumunda ise birkaç hafta süre ile $1-2 \mathrm{mg} / \mathrm{kg} / \mathrm{gün}$ (maksimum $60 \mathrm{mg} /$ gün) dozunda sistemik prednizolon kullanılabilir. Tedavi bırakıldığında relaps olasılığı fazladır, bu yüzden sistemik steroidlerin sadece çok ağır durumlarda kullanılması ve yan etkileri açısından dikkatli olunması gerekmektedir (13-16).

\section{KAYNAKLAR}

1. Liacouras CA, Furuta GT, Hirano I, et al. Eosinophilic esophagitis: updated consensus recommendations for children and adults. J Allergy Clin Immunol 2011;128:3-20.

2. Rothenberg ME. Eosinophilic gastrointestinal disorders (EGID). J Allergy Clin Immunol 2004;113:11-28.

3. Fox VL, Nurko S, Furuta GT. Eosinophilic esophagitis: it's not just kid's stuff. Gastrointest Endosc 2002;56:260-70.

4. Prasad GA, Alexander JA, Schleck CD, et al. Epidemiology of eosinophilic esophagitis over three decades in Olmsted County, Minnesota. Clin Gastroenterol Hepatol 2009;7:1055-61.

5. Hruz P, Straumann A, Bussmann C, et al; Swiss EoE study group. Escalating incidence of eosinophilic esophagitis: a 20-year prospective, population-based study in Olten County, Switzerland. J Allergy Clin Immunol 2011; 128:1349-50.

6. Spergel JM, Andrews T, Brown-Whitehorn TF, et al. Treatment of eosinophilic esophagitis with spesific food elimination diet directed by a combination of skin prick and patch tests. Ann Allergy Asthma Immunol 2005;95:336-43.

7. Simon D, Marti $H$, Heer $P$, Simon HU, et al. Eosiniphilic esophagitis is frequently associated with IgE-mediated allergic airway diseases. J Allergy Clin Immuno 2005; 115:1090-2.

8. Fogg IM, Ruchelli E, Spergel JM. Pollen and eosinophilic esophagitis. J Allergy Clin Immunol 2003;112:796-7.

9. Croese J, Fairley SK, Masson JW, et al. Clinical and endoscopic features of eosinophilic esophagitis in adults. Gastrointest Endosc 2003; 58:516-22.

10. Mackenzie SH, Go M, Chadwick B, et al. Eosinophilic oesophagitis in patients presenting with dysphagia--a prospective analysis. Aliment Pharmacol Ther 2008;28:1140-6.

11. Aceves SS, Ackerman SJ. Relationships between eosinophilic inflammation, tissue remodeling, and fibrosis in eosinophilic esophagitis. Immunol Allergy Clin North Am 2009;29:197-211.

12. Vazquez-Elizondo G, Ngamruengphong S, Khrisna M, et al. The outcome of patients with oesophageal eosinophilic infiltration after an eight-week trial of a proton pump inhibitor. Aliment Pharmacol Ther 2013;38:1312-9.

13. Arora AS, Perrault J, Smyrk TC. Topical corticosteroid treatment of dysphagia due to eosinophilic esophagitis in adults. Mayo Clin Proc 2003;78:830-5.

14. Konikoff MR, Noel RJ, Blanchard C, et al. A randomized, double-blind, placebo-controlled trial of fluticasone propionate for pediatric eosinophilic esophagitis. Gastroenterology 2006;131:138191.

15. Dohil R, Newbury R, Fox $L$, et al. Oral viscous budesonide is effective in children with eosinophilic esophagitis in a randomized, placebo-controlled trial. Gastroenterology 2010;139:418-29.

16. Schaefer ET, Fitzgerald JF, Molleston JP, et al. Comparison of oral prednisone and topical fluticasone in the treatment of eosinophilic esophagitis: a randomized trial in children. Clin Gastroenterol Hepatol 2008;6:1673. 